\title{
Major Neurologic Adverse Drug Reactions, Potential Drug-Drug Interactions and Pharmacokinetic Aspects of Drugs Used in COVID-19 Patients with Stroke: A Narrative Review
}

This article was published in the following Dove Press journal:

Therapeutics and Clinical Risk Management

\author{
Parisa Ghasemiyeh (1D ${ }^{1,2}$ \\ Afshin Borhani-Haghighi ${ }^{3}$ \\ Iman Karimzadeh ' \\ Soliman \\ Mohammadi-Samani $\left(\mathbb{D}^{2,4}\right.$ \\ Afsaneh Vazin (1) ${ }^{\prime}$ \\ Anahid Safari $\mathbb{I D}^{5}$ \\ Adnan I Qureshi ${ }^{6}$ \\ 'Department of Clinical Pharmacy, \\ School of Pharmacy, Shiraz University of \\ Medical Sciences, Shiraz, Iran; \\ ${ }^{2}$ Pharmaceutical Sciences Research \\ Center, School of Pharmacy, Shiraz \\ University of Medical Sciences, Shiraz, \\ Iran; ${ }^{3}$ Clinical Neurology Research \\ Center, Shiraz University of Medical \\ Sciences, Shiraz, Iran; ${ }^{4}$ Department of \\ Pharmaceutics, School of Pharmacy, \\ Shiraz University of Medical Sciences, \\ Shiraz, Iran; ${ }^{5}$ Stem Cells Technology \\ Research Center, Shiraz University of \\ Medical Sciences, Shiraz, Iran; ${ }^{6}$ Zeenat \\ Qureshi Stroke Institute and Department \\ of Neurology, University of Missouri, \\ Columbia, MO, USA
}

Correspondence: Afshin Borhani-Haghighi Clinical Neurology Research Center, Shiraz University of Medical Sciences, Shiraz, Iran Tel/Fax +98-7/3-628I572

Email neuro.ab@gmail.com

\begin{abstract}
Stroke has been considered as one of the underlying diseases that increases the probability of severe infection and mortality. Meanwhile, there are ongoing reports of stroke subsequent to COVID-19 infection. In this narrative paper, we reviewed major neurologic adverse drug reactions (ADRs) and pharmacokinetics of drugs which are routinely used for COVID-19 infection and their potential drug-drug interactions (PDDIs) with common drugs used for the treatment of stroke. It is highly recommended to monitor patients on chloroquine (CQ), hydroxychloroquine (HCQ), antiviral drugs, and/or corticosteroids about initiation or progression of cardiac arrhythmias, delirium, seizure, myopathy, and/or neuropathy. In addition, PDDIs of anti-COVID-19 drugs with tissue plasminogen activator (tPA), anticoagulants, antiaggregants, statins, antihypertensive agents, and iodine-contrast agents should be considered. The most dangerous PDDIs were interaction of lopinavir/ritonavir or atazanavir with clopidogrel, prasugrel, and new oral anticoagulants (NOACs).
\end{abstract}

Keywords: SARS-CoV-2, COVID-19, stroke, potential drug-drug interactions, adverse drug reactions, pharmacokinetics

\section{Introduction}

The coronavirus disease 2019 (COVID-19) pneumonia pandemic has spread all over the globe with considerable morbidity and mortality. The severe disease might occur in healthy individuals of any age, but it mostly occurs in adults with older age or predisposing medical comorbidities such as heart disease, diabetes mellitus (DM), hypertension (HTN), chronic lung disease, neoplasm, chronic renal failure. ${ }^{1}$

More than one-third of patients who required intensive care unit (ICU) admission had at least one underlying vascular risk factor. ${ }^{2}$ In addition to respiratory symptoms, COVID-19 can also lead to hematological and cardiac complications. Severe acute respiratory syndrome coronavirus 2 (SARS-CoV-2) infection has been reported to be associated with myocarditis, and cardiac arrhythmias. ${ }^{3}$ Meanwhile, there are reports of hypercoagulable state in COVID-19 infection. There are also reports of increased D-dimer and fibrin degradation products (FDP) in patients with COVID-19 infection, particularly those with severe disease. ${ }^{4,5}$

Apart from the respiratory system as the predominant target of the virus, angiotensin-converting enzyme 2 (ACE2)) receptor, a key cell surface protein facilitating COVID-19 entry to the cells, is found in various cells including vascular endothelium 
and neurons. ${ }^{6}$ The possible association between stroke and SARS-CoV-2 infection appears to be complex and bidirectional. Stroke has been considered as one of the underlying diseases that increase the probability of severe infection and mortality. Among cases with fatalities, $15.4 \%$ had cerebral infarction. ${ }^{7}$ Up to $11 \%$ of hospitalized patients with COVID19 infection suffer from stroke. ${ }^{8}$ The reported mortality is much higher in individuals with both COVID-19 infection and stroke than that observed in patients with stroke who do not have COVID-19 infection. ${ }^{9}$ There are ongoing reports of stroke subsequent to COVID-19 infection. In an unpublished report from China, acute ischemic stroke, cerebral venous sinus thrombosis, and intracerebral hemorrhage were observed in 11, 1, and 1 out of 221 COVID-19 patients, respectively. In patients with ischemic stroke, 6 took aspirin or clopidogrel and 5 received enoxaparin. ${ }^{10}$ In another Chinese case report, 3 patients with COVID-19 infection and multiple infarcts were reported. The authors considered coagulopathy and antiphospholipid antibodies as the major contributing factors. ${ }^{11}$

Medication errors (MEs) and adverse drug reactions (ADRs) are among the major causes of morbi-mortality in the medical wards and ICUs. ${ }^{12}$ Potential drug-drug interactions (PDDIs) are among the preventable causes of MEs. Considering suitable alternative drugs, dose modification, and monitoring clinical presentations of ADRs by doctors and clinical pharmacists may decrease PDDIs. ${ }^{13}$ It has been shown that PDDIs are common among hospitalized patients in the neurology wards, especially among those receiving multiple medications. ${ }^{14}$ In this narrative paper, we reviewed major neurologic ADRs, the pharmacokinetics of medications with potential anti-COVID-19 activity, and their PDDIs with common drugs used for the treatment of stroke.

\section{Search Strategy}

Literature were searched on Pubmed, Scopus, Google Scholar, and Web of Science databases using the key search terms COVID-19, SARS-CoV-2, neurologic ADRs, stroke, cerebrovascular disease, and PDDIs from 1971 until April 2020. In this regard, first titles and abstracts of peer-reviewed articles were reviewed. This search strategy was limited to human studies that were published in the English language.

\section{Pharmacokinetics}

COVID-19 infection and stroke both have a relatively high risk of renal impairment and perhaps even show higher risk when both occur together. In a prospective cohort project on 701 patients with COVID-19 pneumonia infection, ${ }^{15}$ acute kidney injury (AKI) was observed in $5.1 \%$ of hospitalized patients. The rate of AKI was much higher than the $1-2 \%$ rate reported among all hospitalizations in China. ${ }^{16} \mathrm{AKI}$ is also relatively common and seen in $10 \%$ of patients with ischemic stroke and $20 \%$ of patients with hemorrhagic stroke. ${ }^{17}$

According to Table 1, suitable drug selection should be considered especially in COVID-19 patients with the predisposing disease based on pharmacokinetic aspects of drugs. For example, umifenovir which is mainly metabolized via liver should be used with caution in patients with underlying hepatic disease.

Since chloroquine (CQ) and hydroxychloroquine (HQC) have a narrow therapeutic index and toxicity could be occurred with cardiovascular events, these agents should be used with caution in patients with underlying cardiovascular disease. ${ }^{18} \mathrm{CQ}$ in patients who are consuming heparin could enhance the risk of bleeding. Also, CQ in patients who are on digoxin could cause cardiac block. ${ }^{19}$

\section{Adverse Drug Reactions (ADR)}

Potential drugs which are used in COVID-19 pneumonia management have many neurologic ADRs, some of these most important adverse events are listed in Table 2.

\section{Major Neurologic Adverse Drug Reactions (ADRs) Chloroquine (CQ)/Hydroxychloroquine (HCQ) ADRs}

\section{Extrapyramidal Reactions}

There are several reports of CQ/HCQ-induced Parkinsonism, oculogyric crisis, and dystonias. ${ }^{43}$ Another report revealed that extrapyramidal syndrome might also occur after the administration of a single standard dose of CQ. ${ }^{44}$

\section{Hallucination and Psychosis}

Previous studies revealed that CQ could induce psychotic features such as mood disorder (mixed episode), irritability, anxiousness, agitation, and blunted mood. These psychotic features were more common accompanied by positive symptoms, hallucination, and derealization. Also, results revealed that the severity of these hallucinations and psychotic features are not dose-dependent. ${ }^{45}$

\section{Seizure}

Several studies revealed that CQ consumption could induce seizures. It has been suggested that CQ-induced seizure is an idiosyncratic adverse effect. ${ }^{46,47}$ 
Table I A Brief Pharmacokinetic Data of Potential Drugs Used in COVID-19 Management ${ }^{20}$

\begin{tabular}{|c|c|c|c|c|c|c|c|}
\hline $\begin{array}{l}\text { Anti- } \\
\text { Covid-19 } \\
\text { Agent }\end{array}$ & $\begin{array}{l}\text { Bioavailability } \\
\text { (F) }\end{array}$ & $\begin{array}{l}\text { Volume of } \\
\text { Distribution } \\
\left(V_{d}\right)\end{array}$ & $\begin{array}{l}\text { Elimination } \\
\text { half-life } \\
(T \quad 1 / 2)\end{array}$ & $\begin{array}{l}\text { Clearance } \\
\text { (Cl) }\end{array}$ & Distribution & Metabolism & $\begin{array}{l}\text { Route of } \\
\text { Elimination }\end{array}$ \\
\hline $\begin{array}{l}\text { Chloroquine } \\
\text { (CQ) }\end{array}$ & $67-114 \%$ & $200-800 \mathrm{~L} / \mathrm{kg}$ & 20 to 60 days & $0.35-1 \mathrm{~L} / \mathrm{h} / \mathrm{kg}$ & $\begin{array}{l}\text { Wide distribution to } \\
\text { many body tissues } \\
\text { containing the heart, } \\
\text { kidneys, liver, eyes, } \\
\text { leukocytes, and lungs. } \\
\text { It could obtain } \\
\text { prolonged deposition } \\
\text { in the lungs. }\end{array}$ & $\begin{array}{l}\text { Partially hepatic to the main } \\
\text { metabolite, } \\
\text { desethylchloroquine. } \\
\text { Metabolized by CYP2C } 8^{\text {a }} \text {, } \\
\text { CYP3A4, and to a lesser } \\
\text { extent CYP2D6. }\end{array}$ & $\begin{array}{l}\text { Predominantly } \\
\text { eliminated in } \\
\text { the urine. }\end{array}$ \\
\hline $\begin{array}{l}\text { Hydroxy } \\
\text { chloroquine } \\
(\mathrm{HCQ})\end{array}$ & $67-74 \%$ & $63 \mathrm{~L} / \mathrm{kg}$ & 20 to 120 days & $5.76 \mathrm{~L} / \mathrm{h}$ & $\begin{array}{l}\text { In comparison with } \\
\text { chloroquine, it has a } \\
\text { more limited } \\
\text { distribution to body } \\
\text { tissues. }\end{array}$ & $\begin{array}{l}\text { Hepatic; metabolites include } \\
\text { bidesethylchloroquine, } \\
\text { desethylhydroxychloroquin, } \\
\text { and desethylchloroquine } \\
\text { Metabolized by CYP2C8, } \\
\text { CYP3A4, and to a lesser } \\
\text { extent CYP2D6 }\end{array}$ & $\begin{array}{l}40-50 \% \text { is } \\
\text { excreted } \\
\text { renally }\end{array}$ \\
\hline Lopinavir & $25 \%$ & $1-1.5 \mathrm{~L} / \mathrm{kg}$ & $6.9 \pm 2.2$ hours & $6-7 \mathrm{~L} / \mathrm{h}$ & $\begin{array}{l}\text { It could be distributed } \\
\text { to body tissues except } \\
\text { the brain. }{ }^{21}\end{array}$ & $\begin{array}{l}\text { Hepatic via CYP3A4; } 13 \\
\text { metabolites identlfied; may } \\
\text { induce its own metabolism }\end{array}$ & $\begin{array}{l}\text { Primarily } \\
\text { eliminated in } \\
\text { the feces ( } 82.6 \\
\pm 2.5 \% \text { ) and } \\
\text { the remaining } \\
\text { excreted in the } \\
\text { urine. }\end{array}$ \\
\hline Ritonavir & $\begin{array}{l}\text { Variable; } \\
\text { increased with } \\
\text { food. }\end{array}$ & $\begin{array}{l}0.41 \pm 0.25 \\
\mathrm{~L} / \mathrm{kg}\end{array}$ & 3 to 5 hours & $8.8 \pm 3.2 \mathrm{~L} / \mathrm{h}$ & $\begin{array}{l}\text { It could obtain a high } \\
\text { concentration in } \\
\text { plasma and lymph } \\
\text { nodes but limited } \\
\text { distribution to body } \\
\text { tissues. }\end{array}$ & $\begin{array}{l}\text { Hepatic via CYP3A4 and } \\
\text { 2D6; five metabolites, low } \\
\text { concentration of an active } \\
\text { metabolite (M-2) achieved } \\
\text { in plasma (oxidative) }\end{array}$ & $\begin{array}{l}\text { Primarily } \\
\text { eliminated in } \\
\text { the feces ( } 86.4 \\
\pm 2.9 \% \text { ) and } \\
\text { the remaining } \\
\text { excreted in the } \\
\text { urine. }\end{array}$ \\
\hline Atazanavir & $\begin{array}{l}60-68 \% \text {; } \\
\text { enhanced with } \\
\text { food. }\end{array}$ & $1.4 \mathrm{~L} / \mathrm{kg}$ & $\begin{array}{l}7 \text { hours } \\
\text { (increased to } \\
12 \text { hours in } \\
\text { hepatically } \\
\text { impaired } \\
\text { patients) }\end{array}$ & $9.4 \mathrm{~L} / \mathrm{h}$ & $\begin{array}{l}\text { It has a highly variable } \\
\text { distribution into body } \\
\text { fluids. }{ }^{22}\end{array}$ & $\begin{array}{l}\text { Hepatic metabolism via } \\
\text { CYP3A, also undergoes } \\
\text { biliary elimination. }\end{array}$ & $\begin{array}{l}\text { Primarily } \\
\text { eliminated in } \\
\text { the feces }(79 \%)\end{array}$ \\
\hline $\begin{array}{l}\text { Interferon- } \\
\text { alpha }\end{array}$ & $\begin{array}{l}\text { IM: } 83 \% \\
\text { SubQ: } 90 \%\end{array}$ & $1.4 \mathrm{~L} / \mathrm{kg}$ & 2 to 3 hours & $0.231 \mathrm{~L} / \mathrm{h} / \mathrm{kg}$ & $\begin{array}{l}\text { It has wide } \\
\text { distribution to body } \\
\text { tissues especially in } \\
\text { patients with leukemia } \\
\text { (up to } 20 \text {-folds). } \\
\text { Interferon alpha could } \\
\text { not penetrate CSF } \text {. }\end{array}$ & $\begin{array}{l}\text { Primarily renal, filtered and } \\
\text { absorbed at the renal tubule }\end{array}$ & $\begin{array}{l}\text { Renal } \\
\text { clearance }\end{array}$ \\
\hline Umifenovir & $\begin{array}{l}\text { Rapid } \\
\text { absorption }\end{array}$ & Not available & 17 to 21 hours & $99 \pm 34 \mathrm{~L} / \mathrm{h}$ & $\begin{array}{l}\text { It has rapid absorption } \\
\text { and distribution to } \\
\text { different organs and } \\
\text { tissues. }^{23}\end{array}$ & $\begin{array}{l}\text { Mainly metabolized by the } \\
\text { liver, it should be used with } \\
\text { caution in patients with liver } \\
\text { dysfunction. }\end{array}$ & $\begin{array}{l}\text { The major } \\
\text { route of } \\
\text { elimination is } \\
\text { via the feces }\end{array}$ \\
\hline
\end{tabular}

(Continued) 
Table I (Continued).

\begin{tabular}{|c|c|c|c|c|c|c|c|}
\hline $\begin{array}{l}\text { Anti- } \\
\text { CoVID-19 } \\
\text { Agent }\end{array}$ & $\begin{array}{l}\text { Bioavailability } \\
\text { (F) }\end{array}$ & $\begin{array}{l}\text { Volume of } \\
\text { Distribution } \\
\left(\mathbf{V}_{\mathrm{d}}\right)\end{array}$ & $\begin{array}{l}\text { Elimination } \\
\text { half-life } \\
\text { (T } 1 / 2)\end{array}$ & $\begin{array}{l}\text { Clearance } \\
(\mathrm{Cl})\end{array}$ & Distribution & Metabolism & $\begin{array}{l}\text { Route of } \\
\text { Elimination }\end{array}$ \\
\hline Favipiravir & $97.6 \%$ & $11-13.7 \mathrm{~L} / \mathrm{kg}$ & 2 to 5.5 hours & $2.98 \pm 0.30 \mathrm{~L} / \mathrm{h}$ & $\begin{array}{l}\text { It may present rapid } \\
\text { uptake and clearance } \\
\text { from the liver, kidneys, } \\
\text { and intestine during first } \\
\text { dose administration. } \\
\text { But in multiple-dose } \\
\text { administration, plasma } \\
\text { concentration may be } \\
\text { diminished while drug } \\
\text { distribution and } \\
\text { accumulation in the } \\
\text { liver, stomach, and brain } \\
\text { would be enhanced } \\
\text { significantly. }{ }^{24}\end{array}$ & $\begin{array}{l}\text { A genetic variant in digestive } \\
\left.\text { transport [Pgpk }{ }^{c} \text { ABCBI }{ }^{d}\right] \\
\text { and metabolism [aldehyde } \\
\text { oxydase] to an inactive } \mathrm{MI} \text {, } \\
\text { urinary excretion; both } \\
\text { metabolized by and } \\
\text { inhibited by aldehyde } \\
\text { oxidase }\end{array}$ & $\begin{array}{l}\text { Predominantly } \\
\text { renal clearance }\end{array}$ \\
\hline Remdesivir & Not available & Not available & 0.39 hour & Not available & $\begin{array}{l}\text { It has rapid } \\
\text { distribution in } \\
\text { PBMCs }{ }^{e} \text { and } \\
\text { conversion to its } \\
\text { active form. }{ }^{25}\end{array}$ & $\begin{array}{l}\text { Predominantly metabolized } \\
\text { to a triphosphate } \\
\text { metabolite. }\end{array}$ & Not available \\
\hline Tocilizumab & SubQ: $80 \%$ & $0.054 \mathrm{~L} / \mathrm{kg}$ & $\begin{array}{l}\text { Concentration- } \\
\text { dependent; } \\
\text { up to } 16 \text { days }\end{array}$ & $\begin{array}{l}\text { Concentration- } \\
\text { dependent; } \\
\text { Mean: } 0.29 \pm \\
0.10 \mathrm{~mL} / \mathrm{h} / \mathrm{kg}\end{array}$ & $\begin{array}{l}\text { It might distribute to } \\
\text { lymphatic, } \\
\text { hematopoietic, } \\
\text { digestive, endocrine, } \\
\text { muscular, neural, } \\
\text { respiratory, urinary } \\
\text { systems, etc. }{ }^{26} V_{d} \text { in } \\
\text { adults is up to } 2 \text {-folds } \\
\text { in children. }\end{array}$ & Not available & $\begin{array}{l}\text { Biphasic } \\
\text { elimination } \\
\text { from the } \\
\text { circulation }\end{array}$ \\
\hline Ivermectin & $\begin{array}{l}\text { Well absorbed; } \\
\text { Improved } \\
\text { absorption with } \\
\text { high fat meal. }\end{array}$ & 3 to $3.5 \mathrm{~L} / \mathrm{kg}$ & 16 to 18 hours & $1.2 \mathrm{~L} / \mathrm{h}$ & $\begin{array}{l}\text { It may obtain high } \\
\text { drug concentration in } \\
\text { liver and adipose } \\
\text { tissues, but has poor } \\
\text { penetration through } \\
\text { blood brain barrier. }\end{array}$ & $\begin{array}{l}\text { Primarily hepatic } \\
\text { metabolism. }\end{array}$ & $\begin{array}{l}\text { Metabolized in } \\
\text { the liver; } \\
\text { ivermectin } \\
\text { and/or its } \\
\text { metabolites } \\
\text { are excreted } \\
\text { almost } \\
\text { exclusively in } \\
\text { the feces, } \\
\text { Urine }(<1 \%)\end{array}$ \\
\hline Teicoplanin & $\begin{array}{l}\text { Oral: poorly } \\
\text { absorbed } \\
\text { IM: } 90 \%\end{array}$ & $0.86 \mathrm{~L} / \mathrm{kg}$ & $\begin{array}{l}70 \text { to } 100 \\
\text { hours }\end{array}$ & $0.0033 \mathrm{~L} / \mathrm{h} / \mathrm{kg}$ & $\begin{array}{l}\text { Tissue distribution of } \\
\text { teicoplanin is highly } \\
\text { variable. It may } \\
\text { present extensive } \\
\text { distribution to liver } \\
\text { tissue but poor } \\
\text { penetration into } \\
\text { CSF. }^{27}\end{array}$ & $\begin{array}{l}\text { Metabolic transformation } \\
\text { due to hydroxylation in the } \\
\text { omega-2 and omega-I } \\
\text { positions for metabolites I } \\
\text { and 2, respectively, of the } \\
\text { C-10 linear side chain of } \\
\text { component A2-3. }\end{array}$ & Not available \\
\hline
\end{tabular}

(Continued) 
Table I (Continued).

\begin{tabular}{|l|l|l|l|l|l|l|l|}
\hline $\begin{array}{l}\text { Anti- } \\
\text { COVID-19 } \\
\text { Agent }\end{array}$ & $\begin{array}{l}\text { Bioavailability } \\
(\mathbf{F})\end{array}$ & $\begin{array}{l}\text { Volume of } \\
\text { Distribution } \\
\left(\mathbf{V}_{\mathbf{d}}\right)\end{array}$ & $\begin{array}{l}\text { Elimination } \\
\text { half-life } \\
(\mathbf{T ~} \mathrm{T} / 2)\end{array}$ & $\begin{array}{l}\text { Clearance } \\
(\mathbf{C l})\end{array}$ & Distribution & $\begin{array}{l}\text { Metabolism } \\
\text { Elimination }\end{array}$ \\
\hline Azithromycin & $37 \%$ & $31.1 \mathrm{~L} / \mathrm{kg}$ & 68 hours & $37.8 \mathrm{~L} / \mathrm{h}$ & $\begin{array}{l}\text { Extensively distributed } \\
\text { to body tissues } \\
\text { including skin, tonsil, } \\
\text { lungs, sputum, etc. but } \\
\text { has poor distribution } \\
\text { to brain tissues due to } \\
\text { limited CSF } \\
\text { penetration. }\end{array}$ & $\begin{array}{l}\text { Hepatic metabolism to } \\
\text { inactive metabolites }\end{array}$ & $\begin{array}{l}\text { Biliary } \\
\text { excretion } \\
\text { (major route) } \\
\text { Urine }(<6 \%)\end{array}$ \\
\hline
\end{tabular}

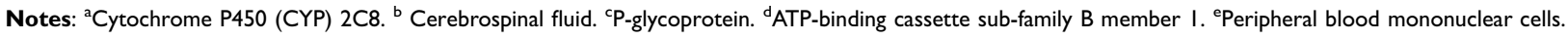

Table 2 The Common Central Nervous System (CNS) and Peripheral Nervous System (PNS) Adverse Effects of Drugs Used in COVID-19 Management

\begin{tabular}{|c|c|c|}
\hline Drug & CNS Adverse Reactions & PNS Adverse Reactions \\
\hline Chloroquine (CQ) & $\begin{array}{l}\text { Acute confusional state, }{ }^{28} \text { delirium },{ }^{29} \text { decreased deep tendon reflex, depression, } \\
\text { extrapyramidal disorders },{ }^{30} \text { seizure }{ }^{31}\end{array}$ & $\begin{array}{l}\text { Myopathy, }{ }^{32} \text { neuromuscular } \\
\text { disease, polyneuropathy }\end{array}$ \\
\hline $\begin{array}{l}\text { Hydroxychloroquine } \\
(\mathrm{HCQ})\end{array}$ & Ataxia, vertigo, dizziness, sensorineural hearing loss, neurosis, psychosis, seizure & Myopathy ${ }^{33}$ \\
\hline Umifenovir & Dizziness, psychiatric symptoms $(0.83 \%)^{34}$ & \\
\hline Lopinavir/Ritonavir & Fatigue, headache, anxiety (4\%), insomnia & Weakness, myalgia \\
\hline Interferon alpha & $\begin{array}{l}\text { Fatigue, headache, depression, drowsiness ( } 1 \text { to } 33 \% \text { ), dizziness, vertigo, malaise, } \\
\text { paresthesia, confusion }(\leq 12) \text {, insomnia }\end{array}$ & $\begin{array}{l}\text { Myalgia, asthenia, musculoskeletal } \\
\text { pain, arthralgia, back pain }\end{array}$ \\
\hline Favipiravir & Psychiatric reactions $(1.72 \%)^{34}$ & \\
\hline Remdesivir & Have not reported yet. & Have not reported yet. \\
\hline Tocilizumab & Headache, dizziness (rare) & $\begin{array}{l}\text { Chronic inflammatory } \\
\text { demyelinating polyneuropathy } \\
(<1 \%)\end{array}$ \\
\hline Corticosteroids & $\begin{array}{l}\left.\text { Psychosis (14\%), }{ }^{35,36} \text { mania (28\%), depression ( } 41 \%\right) \text {, delirium, }{ }^{36} \text { anxiety, }{ }^{36} \\
\text { insomnia, }{ }^{36} \text { seizure, vertigo, paresthesia, }{ }^{37} \text { pseudotumor cerebri }{ }^{38,39}\end{array}$ & Myopathy, ${ }^{40}$ neuropathy ${ }^{41,42}$ \\
\hline
\end{tabular}

Myopathy. Myopathy related to $\mathrm{CQ} / \mathrm{HCQ}$ consumption is a type of reversible vacuolar myopathy. Clinical presentation of this myopathy is very non-selective and patients may experience a mild to moderate muscle weakness, which may also be a common presentation of COVID19 and creatinine kinase (CK) elevation. This myopathy is poorly related to the dose or duration of $\mathrm{CQ} / \mathrm{HCQ}$ therapy but it might be related to the predisposing connective tissue disorders and long-term corticosteroid consumption. Other potential risk factors of CQ/HCQinduced myopathy are renal failure, Caucasian ethnicity, and co-administration of statins, proton pump inhibitors, and other myotoxic agents. ${ }^{48}$

Arrhythmia and Cardiac Reactions. It has been reported that $\mathrm{CQ} / \mathrm{HCQ}$ could induce heart failure, cardiac conductive disorders, and hypertrophic cardiomyopathy which are reversible and could be recovered after discontinuation of therapy. It seems that these cardiac reactions are dosedependent and also more common in patients with underlying renal failure. ${ }^{49,50}$

CQ and HCQ (less likely) could also be associated with QT-prolongation and QT-related malignant arrhythmias. Both 
CQ and HCQ, which are potential agents in COVID-19 management, are metabolized through CYP3A4. In COVID-19 management, if CQ or HCQ administered in combination with antiviral agents (such as lopinavir/ritonavir, atazanavir, remdesivir) or azithromycin which are CYP3A4 inhibitors, the risk of QT-prolongation and drug-induced cardiac death would be enhanced. ${ }^{50,51}$

Maculopathy and Retinopathy. Maculopathy and retinopathy are dose-dependent adverse effects of CQ, especially in the elderly groups, which could be enhanced due to the drug accumulation process. These side effects are more common in total daily doses of over $4 \mathrm{mg} / \mathrm{kg} /$ day. ${ }^{52}$ Since the duration of CQ/HCQ therapy; in COVID-19 patients is short, these ADRs are not restrictive.

Ototoxicity. Ototoxicity has been reported both with $\mathrm{CQ}^{53}$ and less frequently with $\mathrm{HCQ}{ }^{54}$ This ADR may induce hearing loss, tinnitus, vertigo, and disequilibrium. Accordingly, CQ/HCQ ototoxicity may mimic stroke in patients with COVID-19 infection.

Because of these systemic adverse effects related to oral administration of CQ and HCQ, a hypothesis has been suggested that an aerosol formulation of HCQ with a dosage of 2 to $4 \mathrm{mg}$ per inhalation dose, which is one-hundredth of the oral dose, would be considered as an alternative to obtain HCQ therapeutic level in epithelial cells. This low dose formulation with a non-systemic route of administration may minimize adverse drug reactions related to CQ therapy in COVID-19 patients. This novel dosage form might be mostly beneficial in patients with predisposing diseases, elderly groups, and poly-pharmacy patients. ${ }^{55}$

\section{Lopinavir/Ritonavir}

The most common adverse events related to lopinavir/ ritonavir are gastrointestinal adverse effects such as diarrhea, nausea, and vomiting. But other serious adverse reactions such as AKI, respiratory failure, or secondary infection were not observed in patients treated with lopinavir/ritonavir. ${ }^{56}$

\section{Tocilizumab}

Tocilizumab might cause vascular disorders such as hypertension. Also, it could induce nervous system disorders such as headache, demyelinating disorders, leukoencephalopathy with cognitive impairment, and peripheral neuropathy. ${ }^{57}$ A serious adverse effect reported with tocilizumab is increasing the risk of fungal and bacterial infections which should be considered in COVID-19 patients.
Although tocilizumab is not metabolized by the CYP3A4 isoenzyme system, enhanced IL-6 levels had been observed in inflammatory conditions, would inhibit these enzymes, so results in slowing the metabolism of drugs through these pathways. Since CYP3A4 isoenzyme is responsible for the metabolism of many medications, administration of IL-6 inhibitors, such as tocilizumab, could enhance the metabolism of drugs metabolized through the CYP3A4 system such as lopinavir, ritonavir, and atazanavir.

\section{Corticosteroids}

\section{Psychosis}

Corticosteroids could induce psychiatric adverse reactions. Corticosteroid-induced psychosis mostly occurrs as a dosedependent adverse effect but idiosyncratic psychotic reactions were also observed. ${ }^{58-60}$ Since acute psychotic features (ex, delusion and visual or auditory hallucinations) might occur in older patients who have had a stroke, ${ }^{61}$ pay attention to these adverse reactions of corticosteroids in COVID-19 patients who had developed to ARDS with predisposing cerebrovascular diseases is highly crucial.

\section{Seizure}

Corticosteroids could induce convulsion through central mineralocorticoid receptors. This ADR is very rare but it should be considered because of its high clinical importance. ${ }^{62}$ Since seizure is one of the post-stroke complications, so in COVID-19 patients with predisposing cerebrovascular diseases such as stroke, close monitoring during steroid therapy is strongly recommended. The potential mechanism of post-stroke seizure would be the reduction of tonic inhibition. ${ }^{63}$

\section{Anxiety and Agitation}

Corticosteroid consumption could induce mood changes such as anxiety, agitation, and depression. ${ }^{64}$ Generalized anxiety disorder, agitation, and depression are common post-stroke complications. ${ }^{65}$ So, neurologists and clinical pharmacists should be aware of these precipitating ADRs in COVID-19 pneumonia patients with ARDS and history of stroke managed with corticosteroids.

\section{Myopathy}

Steroid myopathy is related to high dose corticosteroid administration and prolonged exposure to steroids. Acute steroid myopathy is a rare but clinically important adverse effect of high dose steroid therapy that presents with 
muscular pain and weakness. ${ }^{66}$ Since this adverse reaction might also be occurred in COVID-19 patients, so close patient monitoring during steroid therapy is highly essential.

\section{Investigational Treatments}

Umifenovir (Arbidol) could induce adverse effects of dizziness and psychiatric symptoms but generally considered safe and could be well-tolerated. Remdesivir is also a well tolerated agent with few serious adverse reactions. Favipiravir might rarely induce drug-related psychotic symptoms.

\section{Angiotensin Converting Enzyme II (ACE2) and COVID- 19}

ACE2 receptor is extensively expressed in various organs such as lungs, intestine, kidneys and blood vessels. It is also presented on the surface of different cells involved in the immune response. ${ }^{67}$ The higher circulating amount of ACE2 was also reported in patients with DM, HTN, and cardiovascular disease (CVD) ${ }^{68}$ It has been hypothesized that ACEIs and angiotensin receptor blockers (ARBs) may increase the possibility of COVID-19 infection or aggravation of its course. ${ }^{68,69}$ However, the Heart Failure Society of America, the American Heart Association, and also the American College of Cardiology recommended that ACEIs and/or ARBs could be continued in patients with robust indications. ${ }^{70}$

\section{Potential Drug-Drug Interactions (PDDIs)}

Based on Infectious Diseases Society of America (IDSA) Guidelines 2020 on the Treatment and Management of
Patients with COVID-19 Infection, CQ/HCQ, fixed dose of lopinavir/ritonavir, tocilizumab, and convalescent plasma could be considered in COVID-19 management in the context of clinical trials. Other drugs that are also under investigation are favipiravir and remdesivir for the management of COVID19 especially in critically ill patients. Some Chinese guidelines are also suggest nebulized interferon-alpha and oral umifenovir (Arbidol) for the treatment of COVID-19, also many supportive therapies have been considered. ${ }^{71-73}$ Also, results of recent studies have revealed that teicoplanin and ivermectin would be promising agents but clinical trials are required to confirm their safety and efficacy in COVID-19 pneumonia management. ${ }^{74,75}$ As many off-label treatments of COVID-19 infections are performed by poly pharmacy with the hope of treatment of a cureless disease, investigation of PDDIs becomes more important.

Table 3 demonstrated a list of PDDIs between drugs used in COVID-19 pneumonia management and common drugs that are used in patients with predisposing cerebrovascular disease. According to Table 3, ${ }^{20,76}$ in COVID-19 patients with cerebrovascular disease who are taking clopidogrel, ticagrelor, and NOACs such as rivaroxaban, administering lopinavir/ritonavir and atazanavir are not suitable for COVID-19 management because of the presence of major drug-drug interactions between these drugs. In these patients, interferon-alpha or other antiviral agents such as favipiravir and remdesivir would be better choices to avoid further complications. Cardiovascular drugs have potential major interactions with antiretroviral agents, so they should be considered by clinicians and clinical pharmacists. Suitable dose modification or

Table 3 Potential Drug-Drug Interactions in COVID-19 Patients with Predisposing Cerebrovascular Diseases

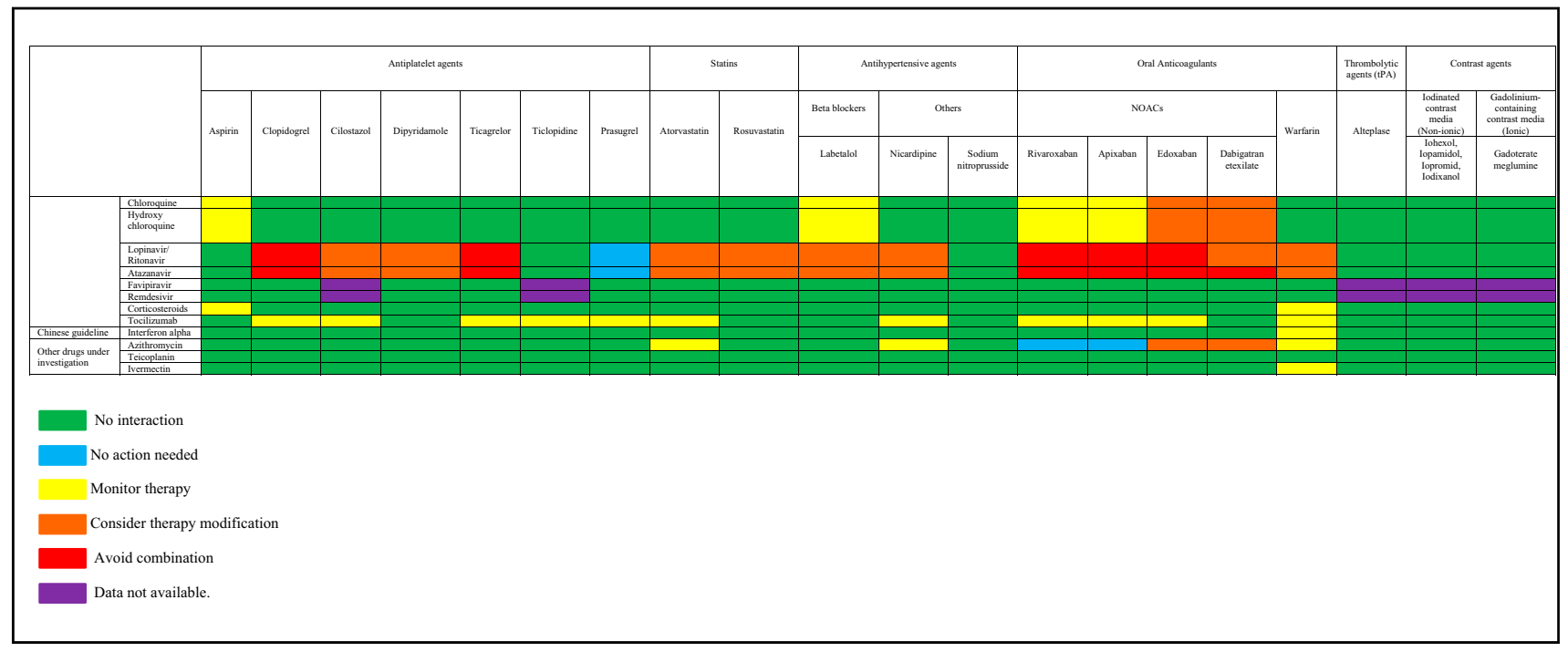


alternative drug selection should be taken into account in these cases. $^{77}$ Possible mechanisms and types of $\mathrm{X}$-category drug-drug interactions and management of these interactions have been shown in Table 4 .

\section{Conclusion}

As it is seen both CQ and HCQ, antiviral agents, and corticosteroids could induce delirium. Delirium occurs very commonly in older hospitalized patients. ${ }^{78}$ The frequency of delirium in stroke patients (13\%- $48 \%)$ is higher than in patients who are admitted to general internal medicine wards (10\%-25\%). ${ }^{79}$ Also, stroke patients have higher mortality and longer hospital stay. Early recognition and prevention of delirium should be considered in patients with stroke and COVID-19 infection. ${ }^{80}$ Pharmacological and non-pharmacological strategies should be considered for the management of delirium. In addition, most importantly PDDIs should be monitored and addressed by clinical pharmacists and neurologists. There are anecdotal and published results of increased prevalence of seizure in patients with COVID-19 infection. ${ }^{81}$ About $5 \%-20 \%$ of stroke victims may develop to seizure. ${ }^{82} \mathrm{~A}$ decreased threshold of seizure in patients with stroke and COVID-19 infection who receive $\mathrm{CQ}, \mathrm{HCQ}$, or corticosteroids should be kept in mind. Metabolic disorders such as hypo/hypernatremia, hypo/hyperglycemia, uremia, and hypocalcemia, which

Table 4 Possible Mechanisms, Types of Interactions, and Management of X-Category Drug-Drug Interactions

\begin{tabular}{|c|c|c|c|}
\hline & $\begin{array}{l}\text { Types of } \\
\text { Interaction }\end{array}$ & Mechanism of Interaction & Interaction Management \\
\hline $\begin{array}{l}\text { Lopinavir/Ritonavir } \\
\text { or Atazanavir plus } \\
\text { Clopidogrel }\end{array}$ & Pharmacokinetic & $\begin{array}{l}\text { Ritonavir and atazanavir might inhibit clopidogrel (a } \\
\text { pro-drug) metabolism to its active metabolite so it } \\
\text { result in the diminished antiplatelet activity. }\end{array}$ & $\begin{array}{l}\text { Avoid combinations and consider possible } \\
\text { alternatives. }\end{array}$ \\
\hline $\begin{array}{l}\text { Lopinavir/Ritonavir } \\
\text { or Atazanavir plus } \\
\text { Ticagrelor }\end{array}$ & Pharmacokinetic & $\begin{array}{l}\text { Strong CYP } 3 A 4^{\mathrm{a}} \text { inhibitors would enhance the } \\
\text { serum concentration of ticagrelor and reduce the } \\
\text { serum concentration of its active metabolites. }\end{array}$ & $\begin{array}{l}\text { Avoid a combination of ticagrelor with strong } \\
\text { CYP3A4 inhibitors and consider alternatives. }\end{array}$ \\
\hline $\begin{array}{l}\text { Lopinavir/Ritonavir } \\
\text { or Atazanavir plus } \\
\text { Rivaroxaban }\end{array}$ & Pharmacokinetic & $\begin{array}{l}\text { Since rivaroxaban is a substrate for both CYP3A4 } \\
\text { isoenzyme and } \mathrm{P} \text {-gP }{ }^{\mathrm{b}} \text {, concomitant administration } \\
\text { of this drug with strong inhibitors of CYP3A4 and } \\
\text { inhibitors of } \mathrm{P} \text {-gP may enhance the serum } \\
\text { concentration of rivaroxaban and risk of major } \\
\text { bleeding. }\end{array}$ & $\begin{array}{l}\text { Avoid a combination of rivaroxaban with strong } \\
\text { CYP3A4 inhibitors and P-gP inhibitors. }\end{array}$ \\
\hline $\begin{array}{l}\text { Lopinavir/Ritonavir } \\
\text { or Atazanavir plus } \\
\text { Apixaban }\end{array}$ & Pharmacokinetic & $\begin{array}{l}\text { These concomitant administrations might result in } \\
\text { inhibition of CYP3A4 mediated metabolism and } \\
\text { P-gP induced efflux of apixaban which may cause } \\
\text { enhanced serum concentration of apixaban and } \\
\text { bleeding complications. }\end{array}$ & $\begin{array}{l}\text { A combination of apixaban with strong CYP3A4 } \\
\text { inhibitors and P-gP inhibitors is contraindicated. }\end{array}$ \\
\hline $\begin{array}{l}\text { Lopinavir/Ritonavir } \\
\text { or Atazanavir plus } \\
\text { Edoxaban }\end{array}$ & Pharmacokinetic & $\begin{array}{l}\text { Inhibitors of } P-g P / A B C B I^{c} \text { might enhance the } \\
C_{\max }{ }^{d}, A U C^{e} \text {, and anticoagulant effect of } \\
\text { edoxaban. }\end{array}$ & $\begin{array}{l}\text { A combination of edoxaban with P-gP/ABCBI } \\
\text { inhibitors should be avoided or dose adjustment } \\
\text { should be considered in patients with venous } \\
\text { thromboembolism. No dosage modification is } \\
\text { available in patients with non-valvular atrial } \\
\text { fibrillation. }\end{array}$ \\
\hline $\begin{array}{l}\text { Lopinavir/Ritonavir } \\
\text { or Atazanavir plus } \\
\text { Dabigatran } \\
\text { etexilate }\end{array}$ & Pharmacokinetic & $\begin{array}{l}\text { Inhibitors of } \mathrm{P}-\mathrm{gp} / \mathrm{ABCB} \text { I could enhance the serum } \\
\text { concentration of active metabolites of dabigatran } \\
\text { etexilate, which is a pro-drug agent. These drug- } \\
\text { drug interactions would be significantly } \\
\text { precipitated in patients with moderate to severe } \\
\text { renal failure. }\end{array}$ & $\begin{array}{l}\text { Avoid combination or consider therapy } \\
\text { modification. } \\
\text { Dose adjustment may also be considered } \\
\text { according to the patients' renal function, } \\
\text { dabigatran etexilate indications, and labeling } \\
\text { recommendations. }\end{array}$ \\
\hline
\end{tabular}

Notes: a Cytochrome P450 (CYP) 3A4. ${ }^{b}$ P-glycoprotein. ${ }^{\mathrm{C}}$ ATP-binding cassette sub-family B member I. ${ }^{\mathrm{d}}$ Max serum concentration. ${ }^{\mathrm{e}}$ Area under the curve. 
decrease the threshold of seizure activity, should be corrected. The probability of non-convulsive status epilepticus as a cause of altered mental function in the patients with COVID-19 infection should also be considered. As patients with COVID-19 infection and stroke may experience prolonged ICU admission, they are susceptible to critical illness myopathy, neuropathy, or polyneuromyopathy and consequently prolonged mechanical ventilation. ${ }^{83}$ Among drugs that have been used for treatments of COVID-19 infection, CQ, HCQ, antivirals, and corticosteroids may induce myopathy and/or neuropathy. Therefore, ADR of these drugs may contribute to failure to wean from ventilators.

As conclusion, in patients with stroke and COVID-19 infection who are taking drugs according to trials or humanitarian use, it is highly recommended to monitor patients to avoid the occurence or progression of cardiac arrhythmias, delirium, seizure, myopathy and/or neuropathy. In addition, PDDIs of anti-COVID-19 drugs with tPA, anticoagulants, antiaggregants, statins, antihypertensive agents, and iodinecontrast agents should be considered. The most harmful PDDIs were interaction of Lopinavir/Ritonavir or Atazanavir with clopidogrel, prasugrel, and NOACs. In these situations, early intervention of neurologists and clinical pharmacists is essential to avoid further disabling toxicity complications.

\section{Author Contributions}

All authors made substantial contributions to conception and design, acquisition of data, or analysis and interpretation of data; took part in drafting the article or revising it critically for important intellectual content; gave final approval of the version to be published; and agree to be accountable for all aspects of the work.

\section{Disclosure}

The authors have no conflict of interest.

\section{References}

1. Guan W-J, Liang W-H, Zhao Y, et al. Comorbidity and its impact on 1590 patients with Covid-19 in China: a nationwide analysis. Eur Respir J. 2020;55(5):2000547. doi:10.1183/13993003.00547-2020

2. Wang D, Hu B, Hu C, et al. Clinical characteristics of 138 hospitalized patients with 2019 novel coronavirus-infected pneumonia in Wuhan, China. JAMA. 2020;323(11):1061-1069. doi:10.1001/jama.2020.1585

3. Madjid M, Safavi-Naeini P, Solomon SD, Vardeny O. Potential effects of coronaviruses on the cardiovascular system: a review. JAMA Cardiol. 2020

4. Bernheim A, Mei X, Huang M, et al. Chest CT findings in coronavirus disease-19 (COVID-19): relationship to duration of infection. Radiology. 2020;200463.
5. Tang N, Li D, Wang X, Sun Z. Abnormal coagulation parameters are associated with poor prognosis in patients with novel coronavirus pneumonia. J Thromb Haemostasis. 2020;18(4):844-847. doi:10.1111/jth.14768

6. Zhou P, Yang X-L, Wang X-G, et al. A pneumonia outbreak associated with a new coronavirus of probable bat origin. Nature. 2020;579(7798):270-273. doi:10.1038/s41586-020-2012-7

7. Deng S-Q, Peng H-J. Characteristics of and public health responses to the coronavirus disease 2019 outbreak in China. J Clin Med. 2020;9(2):575. doi:10.3390/jcm9020575

8. Group C-S. Characteristics of COVID-19 Patients Dying in Italy: Report Based on Available Data on March 20th, 2020. Rome, Italy: Instituto Superiore Di Sanita; 2020.

9. Jin $\mathrm{H}$, Hong $\mathrm{C}$, Chen $\mathrm{S}$, et al. Consensus for prevention and management of coronavirus disease 2019 (COVID-19) for neurologists. Stroke Vasc Neurol. 2020;svn-2020-000382.

10. Xu X, Han M, Li T, et al. Effective treatment of severe COVID-19 patients with tocilizumab. ChinaXiv Preprint. 2020.

11. Zhang Y, Xiao M, Zhang S, et al. Coagulopathy and antiphospholipid antibodies in patients with Covid-19. $N$ Engl J Med. 2020;382(17): e38. doi:10.1056/NEJMc2007575

12. Vazin A, Fereidooni M. Determining frequency of prescription, administration and transcription errors in internal intensive care unit of Shahid Faghihi Hospital in Shiraz with direct observation approach. Iran J Pharmaceut Sci. 2012;8(3):189-194.

13. Namazi S, Borhani-Haghighi A, Karimzadeh I. Adverse reactions to antiepileptic drugs in epileptic outpatients: a cross-sectional study in Iran. Clin Neuropharmacol. 2011;34(2):79-83. doi:10.1097/ WNF.0b013e318210ece0

14. Namazi S, Pourhatami S, Borhani-Haghighi A, Roosta S. Incidence of potential drug-drug interaction and related factors in hospitalized neurological patients in two Iranian teaching hospitals. Iran $J$ Med Sci. 2014;39(6):515.

15. Cheng Y, Luo R, Wang K, et al. Kidney disease is associated with inhospital death of patients with COVID-19. Kidney Int. 2020.

16. Yang L, Xing G, Wang L, et al. Acute kidney injury in China: a cross-sectional survey. The Lancet. 2015;386(10002):1465-1471. doi:10.1016/S0140-6736(15)00344-X

17. Arnold J, Ng KP, Sims D, Gill P, Cockwell P, Ferro C. Incidence and impact on outcomes of acute kidney injury after a stroke: a systematic review and meta-analysis. BMC Nephrol. 2018;19(1):283. doi:10.1186/s12882-018-1085-0

18. Touret F, de Lamballerie X. Of chloroquine and COVID-19. Antiviral Res. 2020;177:104762. doi:10.1016/j.antiviral.2020.104762

19. Wang Y, Zhu LQ. Pharmaceutical care recommendations for antiviral treatments in children with coronavirus disease 2019. World $J$ Pediatr. 2020. doi:10.1007/s12519-020-00353-5

20. Available from: https://epidemio.wiv-isp.be/ID/Documents/Covid19/COVID19_InterimGuidelines_Treatment_ENG.pdf. Accessed June 11, 2020.

21. Kumar GN, Jayanti VK, Johnson MK, et al. Metabolism and disposition of the HIV-1 protease inhibitor lopinavir (ABT-378) given in combination with ritonavir in rats, dogs, and humans. Pharm Res. 2004;21(9):1622-1630. doi:10.1023/B:PHAM.0000 $041457.64638 .8 \mathrm{~d}$

22. Le Tiec C, Barrail A, Goujard C, Taburet A-M. Clinical pharmacokinetics and summary of efficacy and tolerability of atazanavir. Clin Pharmacokinet. 2005;44(10):1035-1050. doi:10.2165/00003088200544100-00003

23. Proskurnina EV, Izmailov DY, Sozarukova MM, Zhuravleva TA, Leneva IA, Poromov AA. Antioxidant potential of antiviral drug umifenovir. Molecules. 2020;25(7):1577. doi:10.3390/molecules 25071577

24. Du YX, Chen XP. Favipiravir: pharmacokinetics and concerns about clinical trials for 2019-nCoV infection. Clin Pharmacol Ther. 2020.

25. Ko W-C, Rolain J-M, Lee N-Y, et al. Arguments in favour of remdesivir for treating SARS-CoV-2 infections. Int $J$ Antimicrob Agents. 2020;55(4):105933. doi:10.1016/j.ijantimicag.2020.105933 
26. Kato A, Watanabe T, Yamazaki M, Deki T, Suzuki M. IL-6R distribution in normal human and cynomolgus monkey tissues. Regul Toxicol Pharmacol. 2009;53(1):46-51. doi:10.1016/j.yrtph.2008.10.007

27. Wilson APR. Clinical pharmacokinetics of teicoplanin. Clin Pharmacokinet. 2000;39(3):167-183. doi:10.2165/00003088-200039 030-00001

28. Mai NTH, Day NP, Van Chuong L, et al. Post-malaria neurological syndrome. The Lancet. 1996;348(9032):917-921. doi:10.1016/ S0140-6736(96)01409-2

29. O'Shaughnessy TJ, Zim B, Ma W, et al. Acute neuropharmacologic action of chloroquine on cortical neurons in vitro. Brain Res. 2003;959(2):280-286. doi:10.1016/S0006-8993(02)03763-0

30. Simooya OO. Antiprotozoal Drugs. Side Effects of Drugs Annual. 36. Elsevier; 2014:393-400.

31. Tristano AG, Falcón L, Willson M, de Oca IM. Seizure associated with chloroquine therapy in a patient with systemic lupus erythematosus. Rheumatol Int. 2004;24(5):315-316. doi:10.1007/s00296-003-0435-8

32. Hughes JT, Oxbury EM, Whitty JC. Chloroquine myopathy. QJM. 1971;40(1):85-93.

33. Abdel-Hamid H, Oddis CV, Lacomis D. Severe hydroxychloroquine myopathy. Muscle Nerve. 2008;38(3):1206-1210. doi:10.1002/ mus. 21091

34. Chen C, Huang J, Cheng Z, et al. Favipiravir versus Arbidol for COVID-19: a randomized clinical trial. medRxiv. 2020.

35. Perantie DC, Brown ES. Corticosteroids, immune suppression, and psychosis. Curr Psychiatry Rep. 2002;4(3):171-176. doi:10.1007/ s11920-002-0023-8

36. Brown ES, Khan DA, Nejtek VA. The psychiatric side effects of corticosteroids. Ann Allergy Asthma Immunol. 1999;83(6):495-504. doi:10.1016/S1081-1206(10)62858-X

37. Ling MH, Perry PJ, Tsuang MT. Side effects of corticosteroid therapy: psychiatric aspects. Arch Gen Psychiatry. 1981;38(4):471-477. doi:10.1001/archpsyc.1981.01780290105011

38. Walker AE, Adamkiewicz J. Pseudotumor cerebri associated with prolonged corticosteroid therapy: reports of four cases. JAMA. 1964;188(9):779-784. doi:10.1001/jama.1964.03060350005001

39. Liu GT, Kay MD, Bienfang DC, Schatz NJ. Pseudotumor cerebri associated with corticosteroid withdrawal in inflammatory bowel disease. Am J Ophthalmol. 1994;117(3):352-357. doi:10.1016/ S0002-9394(14)73145-9

40. Levin OS, Polunina AG, Demyanova MA, Isaev FV. Steroid myopathy in patients with chronic respiratory diseases. J Neurol Sci. 2014;338(1-2):96-101. doi:10.1016/j.jns.2013.12.023

41. Bird SJ, Sladky JT. Brief communications: Corticosteroid-responsive dominantly inherited neuropathy in childhood. Neurology. 1991;41 (3):437. doi:10.1212/WNL.41.3.437

42. Rebolleda G, Pérez-López M, Casas-LLera P, Contreras I, MuñozNegrete FJ. Visual and anatomical outcomes of non-arteritic anterior ischemic optic neuropathy with high-dose systemic corticosteroids. Graefe's Arch Clin Exp Ophthalmol. 2013;251(1):255-260. doi:10.1007/s00417-012-1995-7

43. Parmar R, Valvi C, Kamat JR, Vaswani R. Chloroquine induced parkinsonism. J Postgrad Med. 2000;46(1):29.

44. Busari OA, Fadare J, Agboola S, Gabriel O, Elegbede O, Oladosu Y. Chloroquine-induced acute dystonic reactions after a standard therapeutic dose for uncomplicated malaria. Sultan Qaboos Univ Med J. 2013;13(3):E476. doi:10.12816/0003278

45. Biswas PS, Sen D, Majumdar R. Psychosis following chloroquine ingestion: a 10-year comparative study from a malaria-hyperendemic district of India. Gen Hosp Psychiatry. 2014;36(2):181-186. doi:10.1016/j.genhosppsych.2013.07.012

46. Luijckx G, de Krom M, Takx-Kohlen B. Does chloroquine cause seizures? Presentation of three new cases and a review of the literature. Seizure. 1992;1(3):183-185. doi:10.1016/1059-1311(92)90023-T
47. Krzeminski P, Lesiak A, Narbutt J. Seizures as a rare adverse effect of chloroquine therapy in systemic lupus erythematosus patients: a case report and literature survey. Advan Dermatol Allergol/ Postepy Dermatologii I Alergologii. 2018;35(4):429. doi:10.5114/ada.2018. 77675

48. Khosa S, Khanlou N, Khosa GS, Mishra SK. Hydroxychloroquineinduced autophagic vacuolar myopathy with mitochondrial abnormalities. Neuropathology. 2018;38(6):646-652. doi:10.1111/neup. 12520

49. Baguet J, Tremel F, Fabre M. Chloroquine cardiomyopathy with conduction disorders. Heart. 1999;81(2):221-223. doi:10.1136/ hrt.81.2.221

50. Jafari A, Dadkhahfar S, Perseh S. Considerations for interactions of drugs used for the treatment of COVID-19 with anti-cancer treatments. Crit Rev Oncol Hematol. 2020;102982.

51. Giudicessi JR, Noseworthy PA, Friedman PA, Ackerman MJ, editors. Urgent guidance for navigating and circumventing the QTc-prolonging and torsadogenic potential of possible pharmacotherapies for coronavirus disease 19 (COVID-19). Mayo Clinic Proceedings; 2020: Elsevier.

52. Elman A, Gullberg R, Nilsson E, Rendahl I, Wachtmeister L. Chloroquine retinopathy in patients with rheumatoid arthritis. Scand J Rheumatol. 1976;5(3):161-166. doi:10.3109/03009747609165456

53. Hadi U, Nuwayhid N, Hasbini AS. Chloroquine ototoxicity: an idiosyncratic phenomenon. Otolaryngol Head Neck Surg. 1996;114 (3):491-493. doi:10.1016/S0194-5998(96)70226-7

54. Khalili H, Dastan F, Manshadi SAD. A case report of hearing loss post use of hydroxychloroquine in a HIV-infected patient. DARU J Pharmaceut Sci. 2014;22(1):20. doi:10.1186/2008-2231-22-20

55. Klimke A, Hefner G, Will B, Voss U. Hydroxychloroquine as an aerosol might markedly reduce and even prevent severe clinical symptoms after SARS-CoV-2 infection. Med Hypotheses. 2020;109783.

56. Cao B, Wang Y, Wen D, et al. A trial of lopinavir-ritonavir in adults hospitalized with severe Covid-19. N Engl J Med. 2020;382 (19):1787-1799. doi:10.1056/NEJMoa2001282

57. Koryürek ÖM, Kalkan G. Tocilizumab: a new alternative therapy in dermatology. Immunomodulatory Immunosuppressive Drugs Dermatol. 2016;271.

58. Hackett ML, Köhler S, T O'Brien J, Mead GE. Neuropsychiatric outcomes of stroke. Lancet Neurol. 2014;13(5):525-534.

59. Hodgins GE, Saltz SB, Gibbs EP, Gonzalez R, Regan J, Nemeroff C. Steroid-Induced Psychosis in the Pediatric Population: A New Case and Review of the Literature. $J$ Child Adolesc Psychopharmacol. 2018;28(5):354-359.

60. Campbell R, Tycon L, Pruskowski J. Corticosteroid-Induced Psychiatric Symptoms\# 323. J Palliat Med. 2017;20(3):298-299. doi:10.1089/jpm.2016.0475

61. McMurtray A, Tseng B, Diaz N, Chung J, Mehta B, Saito E. Acute psychosis associated with subcortical stroke: comparison between basal ganglia and mid-brain lesions. Case Rep Neurol Med. 2014;2014.

62. KHAN MJ, GILLANI S. Corticosteroid induced generalized seizures in a nephrotic child with iatrogenic cushing syndrome. Pak Pediatr J. 2018;42(2):135-139.

63. Jaenisch N, Liebmann L, Guenther M, Hübner CA, Frahm C, Witte OW. Reduced tonic inhibition after stroke promotes motor performance and epileptic seizures. Sci Rep. 2016;6:26173. doi:10.1038/srep26173

64. Ou G, Bressler B, Galorport C, et al. Rate of corticosteroid-induced mood changes in patients with inflammatory bowel disease: A prospective study. J Can Assoc Gastroenterol. 2018;1(3):99-106. doi:10.1093/jcag/gwy023

65. Tarawneh R, Cummings J. Depression, psychosis, and agitation in stroke. Primer Cerebrovas Dis. 2017;767-774. 
66. Sun L-Y, Chu X-L. Acute myopathy following intra-muscular injection of compound betamethasone: A case report. Medicine. 2017;96:34.

67. Zou X, Chen K, Zou J, Han P, Hao J, Han Z. Single-cell RNA-seq data analysis on the receptor ACE2 expression reveals the potential risk of different human organs vulnerable to $2019-\mathrm{nCoV}$ infection. Front Med. 2020;1-8.

68. Fang L, Karakiulakis G, Roth M. Antihypertensive drugs and risk of COVID-19?-Authors' reply. Lancet Respir Med. 2020

69. Fang L, Karakiulakis G, Roth M. Are patients with hypertension and diabetes mellitus at increased risk for COVID-19 infection? Lancet Respir Med. 2020;8(4):e21. doi:10.1016/S2213-2600(20)30116-8

70. Association SftAH, America HFSo, Cardiology ACo. Patients taking ACE-i and ARBs who contract COVID-19 should continue treatment, unless otherwise advised by their physician.

71. Dong L, Hu S, Gao J. Discovering drugs to treat coronavirus disease 2019 (COVID-19). Drug Discov Ther. 2020;14(1):58-60. doi:10.5582/ddt.2020.01012

72. Jin Y-H, Cai L, Cheng Z-S, et al. A rapid advice guideline for the diagnosis and treatment of 2019 novel coronavirus $(2019-\mathrm{nCoV})$ infected pneumonia (standard version). Military Med Res. 2020;7 (1):4. doi:10.1186/s40779-020-0233-6

73. Ghasemiyeh P, Mohammadi-Samani S. Iron chelating agents: promising supportive therapies in severe cases of COVID-19? Trends Pharmaceut Sci. 2020;6(2):65-66.

74. Baron SA, Devaux C, Colson P, Raoult D, Rolain J-M. Teicoplanin: an alternative drug for the treatment of coronavirus COVID-19? Int $J$ Antimicrob Agents. 2020;55(4):105944. doi:10.1016/j.ijantimicag.2020. 105944
75. Caly L, Druce JD, Catton MG, Jans DA, Wagstaff KM. The FDAapproved drug ivermectin inhibits the replication of SARS-CoV-2 in vitro. Antiviral Res. 2020;104787.

76. Lai CC, Shih TP, Ko WC, Tang HJ, Hsueh PR. Severe acute respiratory syndrome coronavirus 2 (SARS-CoV-2) and coronavirus disease-2019 (COVID-19): the epidemic and the challenges. Int J Antimicrob Agents. 2020;55(3):105924. doi:10.1016/j.ijantimicag.2020.105924

77. Bansal M. Cardiovascular disease and COVID-19. Diabetes Metabol Syndr. 2020.

78. Lipowski Z. Transient cognitive disorders (delirium, acute confusional sates) in the elderly. Psychos Med Liaison Psychiatry. 1983;289-306.

79. Oldenbeuving A, De Kort P, Jansen B, Roks G, Kappelle L. Delirium in acute stroke: a review. Int J Stroke. 2007;2(4):270-275. doi:10.1111/j.1747-4949.2007.00163.x

80. Connolly ES Jr, Rabinstein AA, Carhuapoma JR, et al. Guidelines for the management of aneurysmal subarachnoid hemorrhage: a guideline for healthcare professionals from the American Heart Association/American Stroke Association. Stroke. 2012;43(6):17111737. doi:10.1161/STR.0b013e3182587839

81. Karimi N, Sharifi Razavi A, Rouhani N. Frequent convulsive seizures in an adult patient with COVID-19: a case report. Iran Red Crescent Med J. In Press.

82. Silverman IE, Restrepo L, Mathews GC. Poststroke seizures. Arch Neurol. 2002;59(2):195-201. doi:10.1001/archneur.59.2.195

83. Shepherd S, Batra A, Lerner DP. Review of critical illness myopathy and neuropathy. Neurohospitalist. 2017;7(1):41-48. doi:10.1177/ 1941874416663279
Therapeutics and Clinical Risk Management

\section{Publish your work in this journal}

Therapeutics and Clinical Risk Management is an international, peerreviewed journal of clinical therapeutics and risk management, focusing on concise rapid reporting of clinical studies in all therapeutic areas, outcomes, safety, and programs for the effective, safe, and sustained use of medicines. This journal is indexed on PubMed Central, CAS,

\section{Dovepress}

EMBase, Scopus and the Elsevier Bibliographic databases. The manuscript management system is completely online and includes a very quick and fair peer-review system, which is all easy to use. Visit http://www.dovepress.com/testimonials.php to read real quotes from published authors. 